\title{
1. Introduction to the Handbook on Austerity, Populism and the Welfare State

\author{
Bent Greve
}

\section{INTRODUCTION}

This chapter sets the scene for the book, including the reasons for the choice of concepts and how and why the link between these are important elements in order to understand societal development in welfare states. It also argues that the presentation and discussion of the development in a variety of different welfare state regimes can be important in order to understand the impact of ideas, ideologies and variations in policies and decisions in a range of countries. Furthermore, the analysis of countries and groups of countries gives one kind of information, but analysis across a number of different sub-sections of the welfare states aims at making it possible to understand in a broader way why there might have been austerity/retrenchment in certain parts of the welfare states, but not necessarily in others. This also includes why populism can have had an impact in certain social policy areas, although not in all of them, as some welfare areas also have, from time to time, strong support from populist parties.

The argument for the choice of framework for the country/regime analysis is based upon classical depictions on welfare regimes (Greve 2019a). Thus, it includes the historical three worlds of welfare capitalism, but other regimes are also included. As retrenchment/austerity has especially been a European discussion, this is the main region to be covered, although other countries are also included to a more limited extent.

In order to understand changes, there is also the need to interpret in a methodological way when and how austerity takes place as well as how this might be influenced by populist traits. This is done in several chapters throughout the book, for example, Chapter 5, but is also touched upon below when setting the scene for the book.

Lastly, this first chapter gives an overview of the chapters in the book.

\section{SETTING THE SCENE}

Austerity has been an issue in welfare state analysis for a long time, and it has even been argued to be a permanent condition (Pierson 2001). Presumably, this reflects the fact that from the 1930 Crisis to 2008, the use of the word 'austerity' in books was at its highest level in the late 1980s, and gradually reduced to a very low level in 2008 just before the last financial crisis. A recent book on austerity (Blyth 2013) has been cited more than 2500 times as of April 2020 , indicating that austerity is a word often used in many books and articles. There has also been increasing interest in the related concept of 'retrenchment'. The difference between these is not always clear-cut (Greve 2020), but more detail can be found in the book's two chapters discussing these concepts. 
Earlier studies have indicated that despite the discussions very few welfare states have seen fundamental shifts (Hacker 2004). It has even been argued that welfare states are often a frozen landscape (Palier and Martin 2007).

One problem with the analysis of austerity and retrenchment is that even if the same amount of, or more, resources are available, there is still also the question of how to prioritize resources and what to focus on in the different welfare states' development (Judd et al. 2015). Thus, it might be that there is reduction in one part of the welfare state, while at the same time expansion in other parts; however, in such cases, the use of the word austerity as a generic term for the development as a whole is misleading.

I have elsewhere defined austerity as both having a possible permanent and more restricted understanding, such that: 'Permanent austerity will be defined as: a constant reduction in the welfare state's position in society and a continuously stronger focus on the market and civil society's role. In contrast to permanent austerity, there can be restricted austerity, causing one or more parts of the welfare states to witness cut-backs - whether in spending or eligibility conditions' (Greve 2020, 21).

This indicates that methodological analysis of austerity needs to have a timeframe so that, for example, a one-year reduction in spending is not understood as austerity given that the following year a return to the previous spending level is possible. It might further be the case that the welfare states continue at the same level, but that the democratic system changes priorities so that one area has less money, but another has been expanded. Therefore, just arguing that there has been austerity or retrenchment without being more precise about what has actually taken place would be misleading. This also includes, for example, taking change in demography and price development into consideration. This might be a reason why 'more generally there is surprisingly little evidence that international economic crisis has led to sudden and fundamental welfare state reform' (Pierson et al. 2016, 264).

There is a long tradition in welfare state analysis for arguing that there has been austerity and/or retrenchment. Thatcher and Reagan are often mentioned as having an agenda of dismantling welfare states; however, they were seemingly not able to make considerable change, as 'on the whole, welfare state programs demonstrated considerable resilience during the tenures of both leaders' (Pierson 1994, 164). The way one can analyse changes related to austerity is to look into change in long-term as well as short-term spending; structure of policy spending; and systemic and programmatic retrenchment (Pierson 1994). This is also an argument for why this book has a number of chapters discussing the concepts and also how they relate to different welfare state regimes both across the board and individually, but also specific sub-sectors of the welfare states.

The reason why populism is also included in the analysis, both conceptually and analytically, is that it may have contributed to a number of changes in welfare states in recent years. This is true in relation to welfare chauvinism, that is, a tendency for welfare to go especially to the citizens of the nation-state and to those considered as deserving to receive these benefits (Greve 2019b). Thus, even if there is not permanent austerity then there might be retrenchment in certain sectors, which is seen by populists as benefits going to non-deserving people, sometimes argued to be welfare scroungers, skivers, lazy unemployed and so on (Hobbins 2016; Trlifajová and Hurrle 2019). Names such as welfare queens, scroungers and skivers indicate partly that the debates are not only related to populist approaches, but also to the narratives' possible impact on welfare states' development (Jurado and Brochmann 2013; Cromby and Willis 2014). 


\section{OVERVIEW OF THE STRUCTURE OF THE BOOK AND INDIVIDUAL CHAPTERS}

The book is divided into five parts, of which this chapter is the first part. The aim in Part II is to present conceptual and methodological issues, followed by welfare state development based upon a country/regime-specific approach in Part III. Part IV then aims to discuss whether one has been witnessing austerity/retrenchment in central welfare state programmes, combined with whether they are more likely than others to be changed. National examples are included.

The regime chapters, in Part III, have the overall intention to describe briefly how to understand the welfare regimes, followed by analysis and interpretation of the changes in the last 10-15 years in order to discuss whether there has been austerity in the different regimes and countries within these. This will be a general discussion but also with examples from different sub-sections of the welfare states.

The chapters on the different policy sectors present the main characteristics and principles of the policy sector, and thereafter discuss changes in recent years, including, depending on the sector, the main drivers for the change ranging from demography, the financial crisis, use of new technology, to the possible impact of populism.

Given the variety of authors and topics, it is not surprising that different positions and interpretations of what has happened can be found. Furthermore, as a consequence of the format of the book, there will also be some overlap between the different chapters.

A short overview of the individual chapters is given below. The book starts with a number of chapters with a focus on definitional and measurement issues.

Chapter 2 by Farnsworth and Irving sets the scene for an understanding of the concept of austerity, although, as argued, it is a slippery concept. This also implies that the measurement hereof might be difficult (see also Chapter 5). However, it is pointed out that it is not only an economic approach that is needed, but also a political one, by referring to the debate about the 'necessary politics'. Finally, what has been done in several countries after the last financial crisis has influenced different sections of society very differently.

Chapter 3 by Starke discusses the concept of retrenchment, arguing that there can be systemic and programmatic retrenchment, and in relation to retrenchment also how key actors and policy-makers react and reflect hereupon. Furthermore, there can be motivational issues, decision making but also informational elements at stake. Finally, the chapter discusses framing and blame-avoidance strategies, including referring to populism in relation to retrenchment, while also concluding that individual attitudes and government strategies are the important aspects related to changes in the welfare states.

Rovira Kaltwasser and Zanotti in Chapter 4 present the concept of populism and link it to the debates on the development of the welfare states, including that populism can imply a challenge for welfare states, especially from welfare chauvinism. A reason being that there can be a difference between who shall be given benefits and who shall pay for them. Finally, they reflect that given populist forces might be more exclusionary or inclusionary this can also have an impact on the direction of changes in welfare states.

Chapter 5 by Ferreira and Howlett focuses on how to measure retrenchment. This is a complex subject given that there are many issues to be aware of in this endeavour including whether to look at institutional change, entitlements, aggregate expenditure data or replacement rates as key measures. The chapter notes how different policy elements can have an impact on outputs and outcomes, also implying that one needs to be aware of how one meas- 
ures developments, including what to and what not to include in the analysis. In this way the chapter also highlights the classical issue of what is the dependent variable, which is the focus of Chapter 6.

Chapter 6 by Kına and Yörük looks precisely into the issue of the dependent variable by first making a systematic literature review, including an overview of the use of different international datasets to see what kind of data is used in order to analyse whether there has been austerity/retrenchment or not, and showing that expenditure is still the most used variable. The analysis of a number of existing studies looking at expenditure, entitlement/rights and legislative impact shows that there is no common knowledge about whether there has actually been retrenchment or not, and in some cases there has only been mixed or partial retrenchment.

Chapter 7 by Blum and Kuhlmann explores the understanding of the concept of welfare in a context of austerity and populism. Definitions of 'the welfare state' are discussed, and key developments of the welfare state throughout the 20th and 21st centuries are highlighted. Many of the changes since the 'Great Recession' have implied a stronger selectivity and tendencies to exclude certain persons from access to different parts of the welfare states. Blum and Kuhlmann highlight three contemporary faces of the austerity-populism nexus: a welfare-hostile, a welfare-friendly, as well as a welfare-ambiguous face. Based on a literature review, they conclude that populist parties today have largely disbanded a welfare-hostile austerity face, but neither are they welfare-friendly per se: the dominant face is that of welfare chauvinism.

Chapter 8 by Béland and Waddan investigates how ideas can be linked to the issues of austerity, populism and the politics of blame. Focusing especially on the UK, there seem to be clear examples, including in relation to Brexit, that there is an interaction between ideas and the use of the options related to austerity. If linked to populist stances, this will be part of how to understand the development. Further, if it can be linked to the issues of not only blame avoidance, but also blame generation to understand the interaction between austerity and populism.

Changes to the welfare state can have an impact on the legitimacy. This is precisely the focus of Chapter 9 where Roosma investigates the change of legitimacy after what is labelled 'the age of austerity'. This is done by looking into how a number of conditions are attached to measuring and understanding legitimacy. Data from the European Social Survey indicate that welfare attitudes, and thereby the legitimacy of the welfare states, are, in fact, rather stable, except that fewer people today believe the welfare states are too costly for companies.

Chapter 10 by Spicker then looks into the relation between austerity and poverty, including a discussion of the ambiguities of the concepts that are being used, highlighting that 'austerity' is often identified, not just with reduced public spending, but with minimal services. As part hereof it shows that the relation is not necessarily the same in all countries between spending on one side and poverty on the other. It is argued that this is only partly due to austerity, as the balance, for example, between public and private provision also has an impact.

Part III deals with how different welfare states in different welfare regimes have coped with the crisis. This part opens with Chapter 11 on the Nordic welfare states by Greve and Kvist, especially how the financial crisis and migration have influenced the development, by looking into change in inequality and a number of policy areas. The chapter concludes that at the overall level there has not been austerity and retrenchment in the Nordic welfare states, while not neglecting that populism has had an impact, especially in relation to migration, and 
thereby change in some social benefits such as unemployment benefits and social assistance has taken place.

Chapter 12 by Heuer analyses the Continental welfare states, and shows that even if they have been described as frozen landscapes there have been strong changes, though mainly before the financial crisis. Despite the relatively strong economy there has been a growth in the populist parties, and they have had to balance their (increasingly working class) voters' wish for more welfare, resulting in opposition to retrenchment, with the aims of their potential (centre-right) coalition partners, resulting in support for retrenchment when in government. Presumably a conflict that also can be witnessed in other welfare states for more right-wing populist parties.

Chapter 13, by Leruth and Taylor-Gooby, looks at the UK as an example of a liberal welfare state where there is a long tradition of having a lean welfare state, with only a limited level of spending. The chapter shows that retrenchment has a long history, and thus is not a new aspect of the development. It further relates the development to the debate on Brexit as well as the issue of migration. Brexit and migration have both added to the uncertainties of the future of the welfare state in the UK, and it is argued that UK welfare chauvinism is shaping a welfare state with strong discrimination between immigrants and denizens.

Southern Europe is one of the regions that bore the brunt of the financial and sovereign debt crisis. In Chapter 14 Petmesidou and Guillén explore reform paths prior to and in the wake of the crisis in this region. Variation in welfare recalibration in the 1990s and 2000s among South European countries was followed by a convergent trend of austerity and retrenchment. In the last few years, recovery has varyingly facilitated the reversal of some unpopular reforms and a slight rise in spending. Yet South European countries have still not returned back to the pre-crisis level in several areas. Trust in institutions has declined and (with the exception of Portugal) populist parties and ideas have surged. Whether the social and economic aftershocks of the COVID-19 pandemic will provide stronger leeway for a populist impact in the future is an open question.

Chapter 15 by Lendvai-Bainton and Stubbs considers developments in Central and South Eastern Europe. The authors show how austerity politics and policies have grown apace in most of the countries in recent years, and that this is driven by right-wing populist parties, including a strong nationalist approach using the window of opportunity to make change supporting a 'deserving', 'ethnicized' middle class, but with negative impact on poverty and inequality. This has also included a stronger role for the market in the delivery of welfare.

In Chapter 16 by Aidukaite the focus is on the Baltic states, which in fact witnessed an expansion in the welfare states shortly after the financial crisis, and since then, however, have seen a number of retrenchment initiatives. In the chapter this is shown by a focus on family policy and especially how benefits in place for a short time are easier to retrench than benefits in place for a long time, thus indicating that welfare policies strongly embedded in a society with support are less likely to witness austerity.

After these presentations of the impact in different welfare regimes, Part IV then moves to the issues of how and whether change has been witnessed in a number of different policy fields within the welfare states.

Chapter 17 by Bridgen looks into pension systems and considers the scale of retrenchment in this area since the 1980s. Using pension expenditure data, adjusted for population, and social rights data for 18 OECD (Organisation for Economic Co-operation and Development countries), he finds retrenchment has been incremental in the large majority of settings. 
Pensioner support has continued strongly in most countries, with respect both to resource allocation and benefit generosity, although there has been a slight reduction in this commitment more recently. This despite the many pensions reforms over the last 30-40 years due to the demographic changes. This does not imply that the changes have been similar across welfare regimes and countries, for example, there has been a reduction in countries such as Germany and Sweden, thereby also questioning regime theory as a basic for understanding change in welfare states.

This is followed by Chapter 18 by Cronert on one of the other central welfare state benefits, that is, unemployment benefits, where the picture is different from the one related to pensions. The trend towards retrenchment in the 1980s and 1990s has continued into the 21 st century, but has taken new forms. While patterns vary across welfare regimes, the overall trend is towards more degressive replacement rates, reduced inclusiveness and stricter conditionality. These changes can be related to both fiscal austerity and populist parties.

Chapter 19 by Ojo then puts the focus on public safety and crime, looking specifically into the case of the UK. Blaming others seems to be a common trend, while there have also been spending cutbacks within the field, which also have an impact on the possibilities and options for doing preventative work. Naturally, this is one of the fields where the cause and effect of change in measures can give rise to a number of different issues to be aware of.

Chapter 20 by Nygård and Kuisma focuses on family policy, a newcomer to social policy. The authors point out that while most European countries increased spending immediately after the financial crisis, there have since been reductions in most countries with regard to cash benefit, whereas the opposite is the case with benefits in kind. This indicates that many countries have adopted an approach that emphasizes the social investment perspective and support towards more gender equality. Remarkably, within one policy area both retrenchment and expansion can take place at the same time. Furthermore, the authors also demonstrate that family policy change in Europe has not been purely about spending. Family policy is also being used as a political tool by European populists, for instance in Hungary and Poland, who have taken an anti-austerity turn by using family policy in promoting nationalist and conservative family values. Long-term care is developed very differently across welfare states, and it is important to analyse whether it has been influenced by the crisis. This is done in Chapter 21 by Da Roit. The chapter shows that changes differ across welfare regimes, partly due to long-term care being a latecomer to social policy in many welfare states. Still, it is also a part of the welfare state where the change in demography has implied an increase in need of welfare state support. Overall, it seems that the crisis has not implied any substantial change in policy.

Chapter 22 by Popova then looks into whether there has been any change in the tax and duty system. It does this by presenting approaches to taxes and duties, and the core challenges to the systems such as globalization, digital economy and population ageing. It is argued that there has been a decline in corporate taxes, less progressivity than earlier, but also that indirect taxes have increased.

In Chapter 23 Adăscăliței and Heyes analyse labour market policies and show that retrenchment to deregulation have not solved the problems of unemployment, underemployment and more broadly the issue of precarity in Europe. Underemployment has even increased in many European countries. The authors also note that in the context of the East-West migration, wages have grown faster than productivity in the new member states.

Not only have classical welfare state areas been influenced by the development in recent years, and in Chapter 24, by Cohen, there is a presentation of the consequences of social 
activism using a UK case study to show how the crisis has implied the need for stronger local activism, including elements such as food-banks and other activities, which might contradict national policies. However, there has also been the pressure of having fewer resources available locally.

It is not obvious that all individuals and groups will be influenced by austerity to the same degree, and this is discussed in Chapter 25 by Kushi and McManus who focus on the impact of austerity measures on gender. They begin by showing the strong differences in unpaid labour across welfare regimes and other data on social spending, public employment and labour market participation rates that affect gender outcomes. They further show that in several welfare states, women have been left more vulnerable than before the crisis, partly due to the fact that gender issues have not been adequately incorporated into policymaking decisions after the Great Recession in several welfare states. The chapter ends with a discussion of gender and welfare regimes in the context of the coronavirus pandemic.

The final Part V comprises Chapter 26 by Greve. It is based upon the analyses within the different chapters and with reference to the recent economic crisis as a consequence of the COVID-19 crisis. It discusses whether this will imply retrenchment and austerity, and if austerity, is it more likely to be partial austerity, given the support in welfare states to have a solid and well-functioning healthcare sector. Naturally, this is a preliminary assessment.

\section{CONCLUDING REMARKS}

Austerity and retrenchment have been central issues in many publications over the last 10-20 years. Populism has more recently become a core topic for analysis of many and very different societies' development. Part of this reflects the constant ongoing changes in societies and also that there are winners and losers from the changes. This is not to imply that everything was better in the good old days and that we should return to a previous time. Instead, there is a need to reflect upon what the consequences have been and might be in the future. Hopefully, this research handbook will help to inform about how to interpret and understand the concepts, how the development has been and what we can learn from the development in the last 10-15 years.

This does not imply that future crises will have the same consequences. Thus, for example, the ongoing, at the time of writing, COVID-19 crisis and its impact on welfare states is difficult to depict. This is due to several reasons, one being that it is still not possible to know how long it will last, but also that the learning effect from the last financial crisis might imply another way of coping with this crisis. Furthermore, a crisis due to natural circumstances might also be perceived differently by voters than an understanding, at least by some, that a crisis was due to greed among the elites of societies.

\section{REFERENCES}

Blyth, Mark. 2013. Austerity: The History of a Dangerous Idea. Oxford: Oxford University Press.

Cromby, John, and Martin E.H. Willis. 2014. 'Nudging into Subjectification: Governmentality and Psychometrics.' Critical Social Policy 34 (2): 241-59.

Greve, B. 2019a. The Routledge Handbook of the Welfare State. Edited by B. Greve. 2nd ed. Oxon: Routledge. 
Greve, B. 2019b. Welfare, Populism and Welfare Chauvinism. Bristol: Policy Press.

Greve, B. 2020. Austerity, Retrenchment and the Welfare State. Truth or Fiction? Cheltenham, UK and Northampton, MA, USA: Edward Elgar Publishing.

Hacker, Jacob S. 2004. 'Privatizing Risk without Privatizing the Welfare State: The Hidden Politics of Social Policy Retrenchment in the United States.' American Political Science Review 98 (2): 243-60. https://doi.org/10.1017/S0003055404001121.

Hobbins, Jennifer. 2016. 'Young Long-Term Unemployed and the Individualization of Responsibility.' Nordic Journal of Working Life Studies 6 (2): 43-59.

Judd, Dawn, Jurgen Boeck, and Aase Madsen. 2015. 'Chicken or Egg? Global Economic Crisis or Ideological Retrenchment from Welfare in Three European Countries.' Critical and Radical Social Work 3 (3): 339-55. https://doi.org/10.1332/204986015X14392797857418.

Jurado, Elena, and Grete Brochmann. 2013. Europe's Immigration Challenge: Reconciling Work, Welfare and Mobility. London: IB Tauris.

Palier, Bruno, and Claude Martin. 2007. 'Editorial Introduction from "a Frozen Landscape" to Structural Reforms: The Sequential Transformation of Bismarckian Welfare Systems.' Social Policy \& Administration 41 (6): 535-54. https://doi.org/10.1111/j.1467-9515.2007.00571.x.

Pierson, C., L. Humpage, P. Fisher, L. Buckner, S. Ronchi, and C. Mills. 2016. 'Coming Together or Drifting Apart? Income Maintenance in Australia, New Zealand, and the United Kingdom.' Politics \& Policy 44 (2): 261-93. https://doi.org/10.1111/polp.12150.

Pierson, P. 1994. Dismantling the Welfare State?: Reagan, Thatcher and the Politics of Retrenchment. Cambridge Studies in Comparative Politics. Cambridge: Cambridge University Press. https://doi.org/ DOI: $10.1017 / \mathrm{CBO} 9780511805288.002$.

Pierson, Paul. 2001. 'Coping with Permanent Austerity Welfare State Restructuring in Affluent Democracies.' In The New Politics of the Welfare State. https://doi.org/10.1109/TELSKS.2011 .6143211 .

Trlifajová, Lucie, and Jakob Hurrle. 2019. 'Work Must Pay: Does It? Precarious Employment and Employment Motivation for Low-income Households.' Journal of European Social Policy 29 (3): 376-95. https://doi.org/10.1177/0958928718805870. 